\title{
Modeling the Effects of Temperature and Gibberellic Acid Concentration on Red Huckleberry Seed Germination
}

\author{
Omar A. Lopez and Danny L. Barney ${ }^{1}$ \\ Department of Plant, Soils, and Entomological Sciences, University of Idaho, \\ Sandpoint R\&E Center, Sandpoint, ID 83864
}

Bahman Shafii and William J. Price

Statistical Programs, College of Agricultural and Life Sciences, University of Idaho, Moscow, ID 83844-2337

\section{Additional index words. Vaccinium parvifolium, logistic regression}

\begin{abstract}
Low seed germination percentages have been reported for red huckleberry (Vaccinium parvifolium Smith). Attempts to improve germination percentages and the speed of germination for red huckleberry are described. Red huckleberry seeds from two collection sites were given gibberellic acid potassium salt (GA-K) treatments $\left(0,500,1000\right.$, and $\left.1500 \mathrm{mg} \cdot \mathrm{L}^{-1}\right)$ and were germinated under three temperature regimens [constant $22^{\circ} \mathrm{C}, 2{ }^{\circ} \mathrm{C}$ day $/ 5{ }^{\circ} \mathrm{C}$ night $\left(22 / 5^{\circ} \mathrm{C}\right)$, and $20^{\circ} \mathrm{C}$ day/13 ${ }^{\circ} \mathrm{C}$ night $\left(20 / 13{ }^{\circ} \mathrm{C}\right)$ with a 12-h photoperiod]. A logistic regression model was used to assess the effects of temperature regimens and GA-K treatments on the maximum cumulative germination percentages, rates of increase, and germination lag times. For seeds untreated with GA-K, the $20 / 13{ }^{\circ} \mathrm{C}$ temperature regime resulted in germination percentages ranging from $30 \%$ to $61 \%$ and lag times (i.e., time to reach one-half of the maximum cumulative germination percentage) of 29 to $35 \mathrm{~d}$ for the two accessions. In comparison, the $22 / 5{ }^{\circ} \mathrm{C}$ temperature regime produced germination percentages of $12 \%$ and $38 \%$ and lag times of 38 to $64 \mathrm{~d}$. The $22{ }^{\circ} \mathrm{C}$ constant temperature produced germination percentages $\leq 1 \%$. Maximum germination percentages of up to $75 \%$ were obtained with $1500 \mathrm{mg} / \mathrm{L}$ GA-K. Rates of germination were generally unaffected by GA-K treatments, and germination lag times were reduced by an average of $10 \mathrm{~d}$ when compared with without GA-K. Improved germination percentages and reduced lag times for red huckleberry seeds were obtained by using a $20 / 13{ }^{\circ} \mathrm{C}$ temperature regime and 1000 to $1500 \mathrm{mg} \cdot \mathrm{L}^{-1}$ GA-K.
\end{abstract}

Red huckleberry is an indigenous $\mathrm{Vacci}$ nium sp. from southeastern Alaska to central California along the Pacific coast and Cascade Mountain ranges, with small disjunct populations reported in southeastern British Columbia (Vander Kloet, 1988). The berries are tart, rather than sweet, and are harvested commercially from the wild for processing. Bearing red leaves in autumn and red berries that remain on the plants into late autumn or early winter, red huckleberry has potential for

Received for publication 11 June 2007. Accepted for publication 14 Sept. 2007.

This paper represents a portion of the thesis Seed and In Vitro Propagation of Vaccinium Species Native to Western North America, submitted by the main author in fulfilling the requirements of a Master of Science degree at the University of Idaho. Funding was provided by the University of Idaho, U.S. Department of Agriculture-Agricultural Research Service Northwest Center for Small Fruit Research, and Hatch Act funds project IDA 01262. Mention of trade or company names does not imply endorsement by the Idaho Agricultural Experiment Station nor criticism of similar products not mentioned.

${ }^{1}$ To whom reprint requests should be addressed; e-maildbarney@uidaho.edu managed commercial fruit production and as an edible ornamental plant. Adaptability to a range of growing sites, vigorous growth, upright habit, and the potential for mechanical harvesting are important traits of this species for breeding programs and commercial production (Barney, 2003).

Little research has been published regarding sexual propagation practices for red huckleberries. Various temperature regimens can affect Vaccinium sp. germination. Although Stark and Baker (1992) reported $70 \%$ germination of $V$. membranaceum at a constant $20{ }^{\circ} \mathrm{C}$, some Vaccinium sp. need temperature fluctuations to germinate (Baskin et al., 2000; Minore et al., 1979; Stushnoff and Hough, 1968; Vander Kloet, 1983). Relatively low germination percentages and a slow germination process are a characteristic of red huckleberry seeds (Vander Kloet, 1983). Vander Kloet (1983) reported up to $47 \%$ germination of freshly extracted red huckleberry seeds under a temperature regime of $22{ }^{\circ} \mathrm{C}$ day $/ 5{ }^{\circ} \mathrm{C}$ night with a $14-\mathrm{h}$ photoperiod (time after harvest of berries not reported). The study also included a $28^{\circ} \mathrm{C}$ day $/ 13{ }^{\circ} \mathrm{C}$ night temperature treatment with a 14 -h photoperiod resulting in $21 \%$ germination, but detailed information about the process of germination (i.e., how seeds germinate over time) was not given.

Gibberellic acid (GA) is used to help break seed dormancy of many angiosperms (Taiz and Zeiger, 2002). For instance, at 4 weeks after treatment with $900 \mathrm{ppm} \mathrm{GA}_{3}$, Dweikat and Lyrene (1989) found 50\% of $V$. corymbosum seeds had germinated, whereas only $4 \%$ of nontreated seeds had germinated. Higher concentrations of $\mathrm{GA}_{3}$ failed to significantly increase germination. In contrast, GA treatments failed to influence $V$. ashei seed germination (Ballington et al., 1976). Similarly, Austin and Cundiff (1978) reported that neither $\mathrm{GA}_{4+7}$ nor $\mathrm{GA}_{4+7}$ plus benzyladenine stimulated $V$. ashei seed germination, although $\mathrm{GA}_{4+7}$-treated seedlings reached transplant size 2 to 4 weeks earlier than did control seedlings or seedlings from $\mathrm{GA}_{3}$-treated seeds. Additionally, Maznaya and Lyanguzova (1999) found that imbibing nonstratified seeds of $V$. uliginosum for $48 \mathrm{~h}$ in 100 to $500 \mathrm{mg} / \mathrm{L} \mathrm{GA}_{3}$ solutions increased the germination percentages from $3 \%$ to between $65 \%$ and $80 \%$.

Devlin and Karczmarczyk $(1975,1977)$ determined that without germination enhancement treatments, $V$. macrocarpon seeds are photoblastic (i.e., require light to germinate) and suggested an interaction between the need for light and GA treatments. Devlin and Karczmarczyk (1975) determined that $V$. macrocarpon seed germination was enhanced in the dark when seeds were soaked with GA after they were treated with concentrated sulfuric acid. The seedcoat is a barrier for the uptake of exogenously applied GA and dark germination was enhanced by GA treatments after seed scarification with concentrated sulfuric acid. In fact, treatment with 1000 ppm GA enhanced seed germination in the light and dark (Devlin and Karczmarczyk, 1977). Smagula et al., (1980) also determined that early germination of $V$. angustifolium seeds kept in the dark was stimulated by GA at 500, 1000, 2000, or 4000 ppm. Unlike $V$. ashei, V. angustifolium seed germination increased with increased GA concentrations in the light.

Therefore, the objectives in conducting this research were to develop a regression model of the germination process for red huckleberry seeds and to use the regression model to assess the effects of temperature and GA concentration on cumulative germination percentage, rate, and lag time of red huckleberry seeds.

\section{Materials and Methods}

Plant materials. Red huckleberry seeds were collected in two locations during Aug. 2003: the Olympic National Forest in Hood Canal Ranger District, Mason County, Washington (accession no. VAPA 023) and near the Mount Saint Helens National Volcanic Monument, Skamania County, Washington (accession no. VAPA 024). Seeds were extracted from fresh ripe fruits using a blender and macerating the berries with a sieve, followed by repeated water washes. 
Seeds were then air dried for $7 \mathrm{~d}$ at room temperature $\left(20^{\circ} \mathrm{C}-22{ }^{\circ} \mathrm{C}\right)$ and put in cold storage at $2{ }^{\circ} \mathrm{C}$ to $4{ }^{\circ} \mathrm{C}$ for 30 months in sealed plastic bags.

Seeds were removed from cold storage and sieved to remove those $<600 \mu \mathrm{m}$ in diameter. Undersized, broken, and deformed seeds were removed under a magnifying lens. Subsamples (i.e., a replication per treatment per accession) of 50 seeds were put into 1.5$\mathrm{mL}$ microcentrifuge tubes and covered with tap water to imbibe the seed. After $24 \mathrm{~h}$, the water was poured off and a $0.45 \%(w: v)$ sodium hypochlorite solution plus three drops of Tween 20 wetting agent per liter of solution was added and left for $20 \mathrm{~min}$ to sterilize the seed surface. Seeds were then rinsed three times for 20 min each with distilled deionized water. Surface sterilization was done before GA potassium salt (GA-K) treatments were applied because sterilization after the treatment seemed to inhibit GA-K effect in preliminary trials (O.A. Lopez, unpublished data). After rinsing the seeds, the microcentrifuge tubes were filled with $1 \mathrm{~mL}$ of distilled deionized water (control) or GA-K solutions at 500, 1000, and 1500 $\mathrm{mg} \cdot \mathrm{L}^{-1}$. Before treatment application, GA-K solution $\mathrm{pH}$ was adjusted to 7 and was filter sterilized using $0.22-\mu \mathrm{m}$ syringe filters (Fisherbrand, Pittsburgh, PA) under sterile conditions in a laminar flow hood.

Tubes were then put in a rotary shaker for $48 \mathrm{~h}$ after which the treatment solutions were removed by aspiration. Seeds were placed into $15-\times 100-\mathrm{mm}$ plastic petri dishes lined with one sheet of sterile filter paper (\#4; Whatman, Maidstone, UK) moistened with $3 \mathrm{~mL}$ of distilled deionized water and then the petri dishes were then sealed with plastic film. Distilled deionized water was added later, as needed, to keep the filter paper moist. Each petri dish represented one replication or experimental unit. A total of four replications per temperature and GA-K treatment were used per each seed accession.

Temperature and light. Thirty-two petri dishes (four GA-K treatments $\times$ two accessions $\times$ four replications) were placed in one incubator per temperature regime. Seeds were treated under three different temperature regimens: $22{ }^{\circ} \mathrm{C}$ constant temperature, $22{ }^{\circ} \mathrm{C}$ day $/ 5{ }^{\circ} \mathrm{C}$ night $\left(22 / 5{ }^{\circ} \mathrm{C}\right)$, and $20{ }^{\circ} \mathrm{C}$ day/13 ${ }^{\circ} \mathrm{C}$ night $\left(20 / 13{ }^{\circ} \mathrm{C}\right)$, all with $12-\mathrm{h}$ photoperiods (model 818; Precision Low Temperature Illuminated Incubators, Winchester, VA). Light in the incubators was provided by Econ-o-watt $\mathrm{F} 34 \mathrm{CW} / \mathrm{RS} / \mathrm{EW}$ $34 \mathrm{~W}$ cool-white fluorescent light tubes. The average light intensity in the fluctuating temperature germination chambers was $15 \mu \mathrm{mol} \cdot \mathrm{m}^{-2} \cdot \mathrm{s}^{-1}$ and was $30 \mu \mathrm{mol} \cdot \mathrm{m}^{-2} \cdot \mathrm{s}^{-1}$ in the constant temperature regime chamber.

Data collection. Seeds were counted as germinated when radical emergence was $\geq 1$ $\mathrm{mm}$ and they were removed from the petri dishes without replacement. Determination of germination began $7 \mathrm{~d}$ after treatment and every $7 \mathrm{~d}$ thereafter for $84 \mathrm{~d}$ in the $22{ }^{\circ} \mathrm{C}$ and $22 / 5{ }^{\circ} \mathrm{C}$ temperature regimens. After $14 \mathrm{~d}$, germination data were collected every 2 to 3 days for $14 \mathrm{~d}$ then every 7 days up to $56 \mathrm{~d}$ for seeds in the $20 / 13{ }^{\circ} \mathrm{C}$ temperature regime. The difference in observation times was designed to ensure that rapid flushes of germination were accurately recorded.

Statistical procedures. A logistic regression model was used previously to describe the seed germination process for $V$. membranaceum (Shafii and Barney, 2001). This model provides parameter estimates for the cumulative germination percentage and speed of germination (rates of increase and lag times). The specific model used was of the form:

$$
\mathrm{y}=\mathrm{M}\left\{1+\exp \left[-\mathrm{K}^{*}(\mathrm{t}-\mathrm{L})\right]\right\}^{-1}
$$

where $\mathrm{y}$ is the cumulative germination percent at time t, $\mathrm{M}$ is the asymptote (theoretical maximum of $\mathrm{y}$ ), $\mathrm{K}$ is the rate of increase, and $\mathrm{L}$ is the lag time, i.e., time to reach $50 \%$ of $\mathrm{M}$.

Nonlinear estimation was carried out separately for each of the eight GA-K-temperature regime treatments within each accession. Cumulative germination percentage results of seeds incubated under $22{ }^{\circ} \mathrm{C}$ constant temperature and untreated with GA-K was only reported because of the very little germination obtained. A weighting procedure (i.e., a process that uses the inverse of the variance and makes the variance to be one when it is zero to evenly distribute residual points) was used during the estimation process to account for changes in germination variability across time. Following model fitting, standard regression residual analysis, graphical plots, and parameter significance

and correlations were used to assess the adequacy of each model. Comparisons of GA-K treatments and temperature regimens were carried out using single and multiple-df contrasts within a full dummy variable model [i.e., a dummy variable model is used to compare parameter estimates of the same model specification, individually (single $\mathrm{df}$ tests) and collectively (multiple df contrasts) among treatments]. The GA-K/temperature treatment comparisons were conducted separately for each accession. All analyses were carried out using SAS (2004; SAS, Cary, NC).

\section{Results and Discussion}

Estimates for maximum cumulative germination $(\mathrm{M})$, rate of increase $(\mathrm{K})$, and time to reach $50 \%$ germination of $\mathrm{M}$ or lag time (L) are shown in Table 1 and were significant $(P \leq 0.05)$ except for the predicted maximum cumulative germination of the control $(0$ $\left.\mathrm{mg} \cdot \mathrm{L}^{-1} \mathrm{GA}-\mathrm{K}\right)$ seeds for VAPA 023 incubated under the $22 / 5{ }^{\circ} \mathrm{C}$ temperature regime. Residual plots for each model showed no patterns or trends, with the majority of the data points within two standard deviations of the mean. An example of a fitted curve and the associated data for the $1500 \mathrm{mg} \cdot \mathrm{L}^{-1}$ GA-K treatment under the $22 / 5{ }^{\circ} \mathrm{C}$ temperature regime is presented in Fig. 1. In this example, $\mathrm{L}$ was $31 \mathrm{~d}$ to reach $50 \%$ of $\mathrm{M}$, which was $75 \%$. The value, $0.18(\mathrm{~K})$, defines the rate of increase. In general higher values of $\mathrm{K}$ lead to faster rates of increase. Other treatment-temperature combinations produced similar fitted curves suitable for treatment comparisons.

Table 1. Parameter estimates of the logistic regression model for seeds of two accessions treated with for four gibberellic acid potassium salt (GA-K) treatments under two temperature regimens.

\begin{tabular}{|c|c|c|c|c|c|c|c|}
\hline \multirow{3}{*}{$\begin{array}{l}\text { Treatments } \\
\left(\mathrm{mg} \cdot \mathrm{L}^{-1} \mathrm{GA}-\mathrm{K}\right)\end{array}$} & \multirow[b]{3}{*}{ Parameter $^{2}$} & \multicolumn{3}{|c|}{$22{ }^{\circ} \mathrm{C} / 5^{\circ} \mathrm{C}$} & \multicolumn{3}{|c|}{$20^{\circ} \mathrm{C} / 13^{\circ} \mathrm{C}$} \\
\hline & & Estimate & SE & $P>\mathrm{t}$ & Estimate & $\mathrm{SE}$ & $P>\mathrm{t}$ \\
\hline & & \multicolumn{6}{|c|}{ VAPA 023} \\
\hline \multirow[t]{3}{*}{0} & M (\%) & 11.50 & 6.40 & 0.07 & 29.70 & 4.00 & $<0.0001$ \\
\hline & $\mathrm{K}$ & 0.08 & 0.04 & 0.04 & 0.14 & 0.02 & $<0.0001$ \\
\hline & L (d) & 64.10 & 17.10 & 0.0002 & 35.00 & 2.60 & $<0.0001$ \\
\hline \multirow[t]{3}{*}{500} & M (\%) & 17.90 & 1.80 & $<0.0001$ & 50.90 & 3.10 & $<0.0001$ \\
\hline & $\mathrm{K}$ & 0.11 & 0.02 & $<0.0001$ & 0.16 & 0.02 & $<0.0001$ \\
\hline & L (d) & 37.80 & 3.80 & $<0.0001$ & 28.80 & 1.30 & $<0.0001$ \\
\hline \multirow[t]{3}{*}{1000} & M (\%) & 24.10 & 1.50 & $<0.0001$ & 39.60 & 2.40 & $<0.0001$ \\
\hline & $\mathrm{K}$ & 0.16 & 0.03 & $<0.0001$ & 0.20 & 0.04 & $<0.0001$ \\
\hline & L (d) & 32.00 & 2.20 & $<0.0001$ & 21.80 & 1.20 & $<0.0001$ \\
\hline \multirow[t]{4}{*}{1500} & M (\%) & 37.20 & 1.90 & $<0.0001$ & 54.10 & 2.40 & $<0.0001$ \\
\hline & $\mathrm{K}$ & 0.17 & 0.03 & $<0.0001$ & 0.20 & 0.03 & $<0.0001$ \\
\hline & $\mathrm{L}(\mathrm{d})$ & 33.50 & 1.90 & $<0.0001$ & 22.90 & 0.80 & $<0.0001$ \\
\hline & & \multicolumn{6}{|c|}{ VAPA 024} \\
\hline \multirow[t]{3}{*}{0} & M (\%) & 37.80 & 2.00 & $<0.0001$ & 61.00 & 3.00 & $<0.0001$ \\
\hline & $\mathrm{K}$ & 0.15 & 0.03 & $<0.0001$ & 0.16 & 0.02 & $<0.0001$ \\
\hline & L (d) & 37.50 & 2.00 & $<0.0001$ & 28.60 & 1.10 & $<0.0001$ \\
\hline \multirow[t]{3}{*}{500} & M (\%) & 49.40 & 1.80 & $<0.0001$ & 68.20 & 2.20 & $<0.0001$ \\
\hline & $\mathrm{K}$ & 0.16 & 0.03 & $<0.0001$ & 0.20 & 0.03 & $<0.0001$ \\
\hline & L (d) & 29.20 & 1.60 & $<0.0001$ & 19.60 & 0.70 & $<0.0001$ \\
\hline \multirow[t]{3}{*}{1000} & M (\%) & 54.60 & 2.00 & $<0.0001$ & 74.00 & 1.80 & $<0.0001$ \\
\hline & $\mathrm{K}$ & 0.13 & 0.02 & $<0.0001$ & 0.26 & 0.03 & $<0.0001$ \\
\hline & L (d) & 32.80 & 1.60 & $<0.0001$ & 18.30 & 0.50 & $<0.0001$ \\
\hline \multirow[t]{2}{*}{1500} & $\mathrm{~K}$ & 0.18 & 0.02 & $<0.0001$ & 0.19 & 0.02 & $<0.0001$ \\
\hline & $\mathrm{L}(\mathrm{d})$ & 30.60 & 0.90 & $<0.0001$ & 20.70 & 0.60 & $<0.0001$ \\
\hline
\end{tabular}

${ }^{\mathrm{z}} \mathrm{M}=$ asymptote (theoretical maximum cumulative germination percentage) $\mathrm{K}=$ rate of increase; $\mathrm{L}=$ lag time (days to reach $50 \%$ of $\mathrm{M}$ ). 
Effects of temperature. In the constant $22{ }^{\circ} \mathrm{C}$ temperature, maximum germination percentages were $0 \%$ and $1 \%$ for VAPA 023 and VAPA 024, respectively, and statistical analysis was not completed because of the low germination percentages obtained. Temperature effects on seed germination were assessed through comparison of model parameter estimates within each accession and temperature regime. The overall regression curves (i.e., the $0 \mathrm{mg} \cdot \mathrm{L}^{-1} \mathrm{GA}-\mathrm{K}$-treated seeds incubated under the $22 / 5{ }^{\circ} \mathrm{C}$ and 20 / $13{ }^{\circ} \mathrm{C}$ temperature regimens) were compared first, followed by subsequent tests on their associated parameter estimates. For both accessions, there were significant differences between the estimated curves for temperature regimens. Further analyses indicated that temperature regime significantly affected $\mathrm{M}$ and $\mathrm{L}$ for the two accessions tested, whereas seeds in both temperature regimens germinated at similar $\mathrm{K}$ (Table 2). The $20 / 13{ }^{\circ} \mathrm{C}$ regime increased $\mathrm{M}$ percentages from $12 \%$ to $30 \%$ and $38 \%$ to $61 \%$ for seeds from accessions VAPA 023 and VAPA 024, respectively, relative to the $22 / 5{ }^{\circ} \mathrm{C}$ regime. Compared with $\mathrm{L}$ in the $22 / 5{ }^{\circ} \mathrm{C}$ regime, $\mathrm{L}$ in the $20 / 13{ }^{\circ} \mathrm{C}$ regime were significantly reduced from $64 \mathrm{~d}$ to $35 \mathrm{~d}$ and $38 \mathrm{~d}$ to $29 \mathrm{~d}$ for accessions VAPA 023 and VAPA 024, respectively.

Based on these results, 30-month coldstored red huckleberry seeds require diurnal temperature fluctuation to germinate. As previously mentioned, other authors also have reported the need for temperature fluctuation to promote germination for Vaccinium species (Baskin et al., 2000; Minore et al., 1979; Stushnoff and Hough, 1968; Vander Kloet, 1983). The results of this trial support these previous reports because seeds incubated under $22{ }^{\circ} \mathrm{C}$ constant temperature failed to germinate or germinated at low germination percentages $(1 \%)$. In our study, the warmer night temperatures of $13{ }^{\circ} \mathrm{C}$ increased coldstored seed germination and reduced $\mathrm{L}$ compared with the $5{ }^{\circ} \mathrm{C}$ night temperature. In contrast, Vander Kloet (1983) reported 47\% germination for fresh seeds under a $22{ }^{\circ} \mathrm{C}$ day $/ 5^{\circ} \mathrm{C}$ night and $14-\mathrm{h}$ photoperiod and only $21 \%$ germination of fresh seeds in a warmer day and night, $28{ }^{\circ} \mathrm{C}$ day $/ 13{ }^{\circ} \mathrm{C}$ night and 12-h photoperiod regime. As opposed to what occurred in our study, the colder night temperature regime in the Vander Kloet (1983) study produced lower germination $(38 \%)$ and longer germination times for dried and coldstored seeds compared with the $61 \%$ germination of cold-stored seed in the warmer night temperature regime. In addition, factors such as drying the fresh seeds and cold storage can affect germination characteristics of Vaccinium species. Vander Kloet (1983) obtained greater germination percentages after seeds were dried and cold stored at $2{ }^{\circ} \mathrm{C}$ for 6 to 12 months for $V$. ovalifolium, $V$. deliciosum, $V$. scoparium, $V$. caespitosum, and $V$. myrtillus. Opposite results were obtained for $V$. parvifolium and $V$. membranaceum. Shafii and Barney (2001) stated that air drying $V$. membranaceum seeds for $7 \mathrm{~d}$

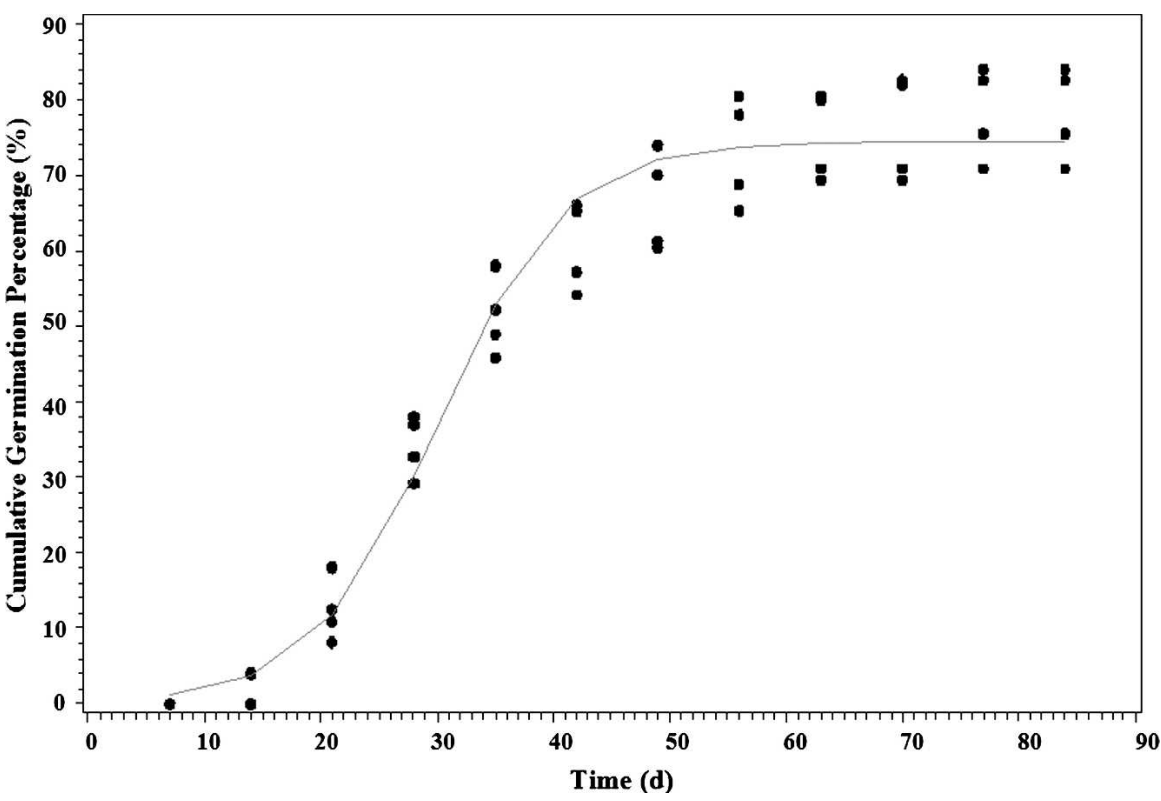

Fig. 1. Estimated logistic regression line with observed data points representing germination of VAPA 024 seeds treated with $1500 \mathrm{mg} \cdot \mathrm{L}^{-1}$ gibberellic acid and incubated under $22{ }^{\circ} \mathrm{C}$ day $/ 5{ }^{\circ} \mathrm{C}$ night temperature regime and a $12-\mathrm{h}$ photoperiod.

Table 2. Contrasts between regression lines of seeds treated with $0 \mathrm{mg} \cdot \mathrm{L}^{-1}$ gibberellic acid potassium salt (GA-K) and parameter estimates of the logistic regression model comparing the effects of two temperature regimens $\left(22{ }^{\circ} \mathrm{C}\right.$ day $/ 5{ }^{\circ} \mathrm{C}$ night and $20{ }^{\circ} \mathrm{C}$ day $/ 13{ }^{\circ} \mathrm{C}$ night and 12 -h photoperiod) on red huckleberry seed germination in two accessions.

\begin{tabular}{lcrr}
\hline Label $^{\mathrm{z}}$ & DF & $F$ value & $P$ \\
\hline VAPA 023 & & & \\
Lines: $22 / 5{ }^{\circ} \mathrm{C}$ vs. $20 / 13{ }^{\circ} \mathrm{C}$ & 3 & 32.59 & $<0.0001$ \\
$\mathrm{M}: 22 / 5{ }^{\circ} \mathrm{C}$ vs. $20 / 13^{\circ} \mathrm{C}$ & 1 & 24.73 & $<0.0001$ \\
$\mathrm{~K}: 22 / 5^{\circ} \mathrm{C}$ vs. $20 / 13{ }^{\circ} \mathrm{C}$ & 1 & 0.74 & 0.3905 \\
L: $22 / 5^{\circ} \mathrm{C}$ vs. $20 / 13{ }^{\circ} \mathrm{C}$ & 1 & 8.12 & \\
VAPA 024 & & & $<0.0053$ \\
Lines: $22 / 5{ }^{\circ} \mathrm{C}$ vs. $20 / 13{ }^{\circ} \mathrm{C}$ & 3 & 61.44 & $<0.0001$ \\
M: $22 / 5{ }^{\circ} \mathrm{C}$ vs. $20 / 13{ }^{\circ} \mathrm{C}$ & 1 & 41.09 & 0.7021 \\
K: $22 / 5{ }^{\circ} \mathrm{C}$ vs. $20 / 13{ }^{\circ} \mathrm{C}$ & 1 & 0.15 & 0.0002 \\
L: $22 / 5^{\circ} \mathrm{C}$ vs. $20 / 13{ }^{\circ} \mathrm{C}$ & 1 & 15.34 & \\
\hline
\end{tabular}

${ }^{2}$ Accessions VAPA 023 and 024. Lines are represented by the logistic regression model Eq. [1]. Lines $=$ contrasts between all three parameter estimates simultaneously $(\mathrm{M}, \mathrm{K}$, and $\mathrm{L})$ where $\mathrm{M}=$ the maximum asymptote (theoretical maximum cumulative percentage), $\mathrm{K}=$ germination rate, and $\mathrm{L}=$ lag time or time to reach $50 \%$ of $\mathrm{M}$.

Table 3. Contrasts between regression lines and parameter estimates of the logistic regression model comparing the effects of gibberellic acid potassium salt (GA-K) on red huckleberry seed germination for two accessions (VAPA 023 and 024) and two temperature regimens $\left(22{ }^{\circ} \mathrm{C} / 5^{\circ} \mathrm{C}\right.$ and $20^{\circ} \mathrm{C} / 13{ }^{\circ} \mathrm{C}$ ).

\begin{tabular}{|c|c|c|c|}
\hline Label $^{z}$ & DF & $F$ value & $P$ \\
\hline \multicolumn{4}{|l|}{ VAPA $023-22 / 5{ }^{\circ} \mathrm{C}$} \\
\hline Lines: control vs. GA & 3 & 25.38 & $<0.0001$ \\
\hline M: control vs. GA & 1 & 5.29 & 0.0225 \\
\hline K: control vs. GA & 1 & 1.89 & 0.1709 \\
\hline L: control vs. GA & 1 & 3.00 & 0.0849 \\
\hline \multicolumn{4}{|l|}{ VAPA $023-20 / 13{ }^{\circ} \mathrm{C}$} \\
\hline Lines: control vs. GA & 3 & 193.25 & $<0.0001$ \\
\hline M: control vs. GA & 1 & 22.66 & $<0.0001$ \\
\hline K: control vs. GA & 1 & 2.66 & 0.1129 \\
\hline L: control vs. GA & 1 & 15.56 & 0.0001 \\
\hline \multicolumn{4}{|l|}{ VAPA $024-22 / 5^{\circ} \mathrm{C}$} \\
\hline Lines: control vs. GA & 3 & 212.57 & $<0.0001$ \\
\hline M: control vs. GA & 1 & 96.71 & $<0.0001$ \\
\hline $\mathrm{K}$ : control vs. GA & 1 & 0.14 & 0.7074 \\
\hline L: control vs. GA & 1 & 9.58 & 0.0023 \\
\hline \multicolumn{4}{|l|}{ VAPA $024-20 / 13{ }^{\circ} \mathrm{C}$} \\
\hline Lines: control vs. GA & 3 & 357.48 & $<0.0001$ \\
\hline M: control vs. GA & 1 & 11.79 & 0.0007 \\
\hline K: control vs. GA & 1 & 7.74 & 0.0059 \\
\hline L: control vs. GA & 1 & 62.79 & $<0.0001$ \\
\hline
\end{tabular}

${ }^{\mathrm{z}}$ Lines are represented by the logistic regression model Eq. [1]. Lines $=$ contrasts between all three parameter estimates simultaneously $(\mathrm{M}, \mathrm{K}$, and $\mathrm{L})$ where $\mathrm{M}=$ the maximum asymptote (theoretical maximum cumulative percentage), $\mathrm{K}=$ rate of increase, and $\mathrm{L}=$ lag time or time to reach $50 \%$ of $\mathrm{M}$. 
reduced $\mathrm{M}$ percentage from $73 \%$ to $59 \%$ compared with fresh seeds although subsequent cold storage at 2 to $4{ }^{\circ} \mathrm{C}$ of the dried seeds restored germination rates to those similar to fresh seeds. In our preliminary trials, fresh and dried seeds of $V$. parvifolium germinated at very low cumulative germination percentages (Lopez, 2006), and data were not modeled because of low germination percentages and high variability. Future research is needed on the effect of cold storage times on $V$. parvifolium seed germination.

The mechanisms of temperature effect on red huckleberry seeds are yet to be determined, but habitat characteristics could explain the dependence on temperature fluctuation for germination. Seed ecology and germination characteristics are associated with habitat adaptation, climate conditions, and the seed position in the soil that are favorable for seed germination and seedling establishment (Baskin et al., 2000; Berrie, 1984; Thompson et al., 1977). For example, Thompson and Grime (1983) stated that sensitivity to temperature fluctuations evolved in boreal wetland species (e.g., Chenopodium rubrum, Rorippa islandica, Gnaphalium ulininosum, and Atripex hastate) as an adaptation to ensure that seeds will germinate when the conditions are more suitable for seedling establishment.

A required warmer daily minimum temperature has been reported in Vaccinium species to promote seed germination. Baskin et al., (2000) reported that Vaccinium myrtillus and $V$. vitis-idaea seeds germinated when minimum daily temperatures were frequently $\geq 10{ }^{\circ} \mathrm{C}$ in late August and early to mid-September, but no seeds of either species germinated during late May where minimum temperatures ranged from $7{ }^{\circ} \mathrm{C}$ to $10^{\circ} \mathrm{C}$.

Based on the results of our study, red huckleberry seed germination is greater in night temperatures of $13{ }^{\circ} \mathrm{C}$ compared with germination at $5{ }^{\circ} \mathrm{C}$. In alpine and subAlpine ecosystems where red huckleberry is adapted, temperatures naturally fluctuate with high temperatures during the day and low temperatures at night (Vander Kloet, 1988).

Effects of $G A-K$. GA-K treatments significantly increased $\mathrm{M}$ percentages for both accessions and germination temperature regimens compared with germination in the control (Table 3). M for VAPA 023 seed at $22 / 5{ }^{\circ} \mathrm{C}$ increased from $12 \%$ to $38 \%$ as the GA-K concentrations increased from 0 to $1500 \mathrm{mg} \cdot \mathrm{L}^{-1}$ (Fig. 2). Specific comparison of the 1000 and $1500 \mathrm{mg} / \mathrm{L}$ GA-K treatments indicates that $\mathrm{M}$ increased in seeds treated with more than $1000 \mathrm{mg} \cdot \mathrm{L}^{-1}$ GA-K (Table 4). VAPA 023 seeds grown under $20 / 13{ }^{\circ} \mathrm{C}$ showed similar responses except that seeds treated with $1000 \mathrm{mg} / \mathrm{L}$ had lower $M$ than those with $500 \mathrm{mg} \cdot \mathrm{L}^{-1}$ (Fig. 3). A contrast between these two treatments (500 vs. $\left.1500 \mathrm{mg} \cdot \mathrm{L}^{-1} \mathrm{GA}-\mathrm{K}\right)$ showed that the $M$ between the mentioned treatments were similar, however (Table 4).

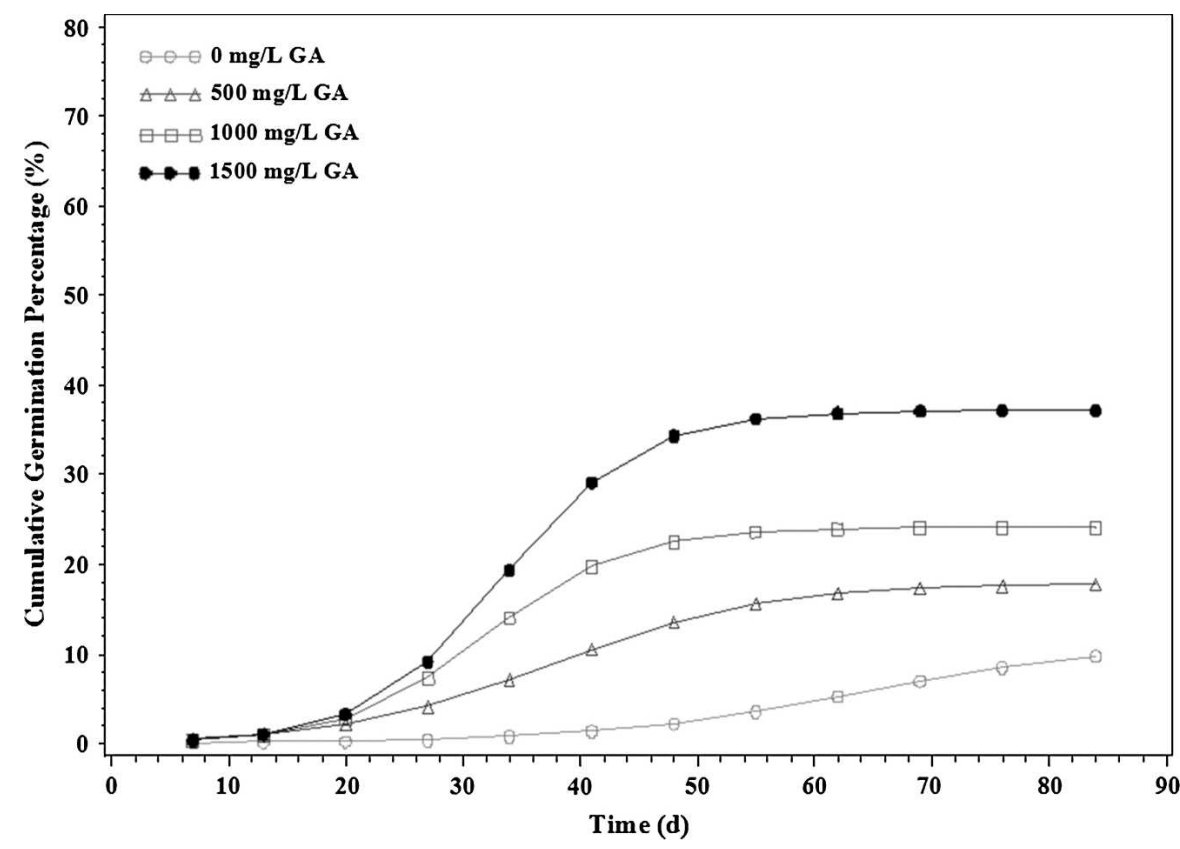

Fig. 2. Estimated logistic regression lines for accession VAPA 023 seeds grown under $22{ }^{\circ} \mathrm{C}$ day $/ 5^{\circ} \mathrm{C}$ night temperatures with a 12 -h photoperiod treated with four gibberellic acid potassium salt (GA-K) treatments.

Table 4. One-df contrasts between parameter estimates of the logistic regression model comparing the effects of gibberellic acid potassium salt (GA-K) doses on red huckleberry seed germination for two accessions (VAPA 023 and 024) and two temperature regimens $\left(22{ }^{\circ} \mathrm{C} / 5^{\circ} \mathrm{C}\right.$ and $\left.20^{\circ} \mathrm{C} / 13{ }^{\circ} \mathrm{C}\right)$.

\begin{tabular}{|c|c|c|c|}
\hline Label $^{z}$ & DF & $F$ value & $P$ \\
\hline \multicolumn{4}{|l|}{ VAPA $023-22 / 5^{\circ} \mathrm{C}$} \\
\hline $\mathrm{M}: 1000$ vs. $1500 \mathrm{mg} \cdot \mathrm{L}^{-1} \mathrm{GA}$ & 1 & 28.67 & $<0.0001$ \\
\hline $\mathrm{K}: 1000$ vs. $1500 \mathrm{mg} \cdot \mathrm{L}^{-1} \mathrm{GA}$ & 1 & 0.01 & 0.9261 \\
\hline $\mathrm{L}: 1000$ vs. $1500 \mathrm{mg} \cdot \mathrm{L}^{-1} \mathrm{GA}$ & 1 & 0.26 & 0.6045 \\
\hline \multicolumn{4}{|l|}{ VAPA $023-20 / 13{ }^{\circ} \mathrm{C}$} \\
\hline M: 500 vs. $1500 \mathrm{mg} \mathrm{GA}$ & 1 & 0.66 & 0.4180 \\
\hline $\mathrm{K}: 500$ vs. $1500 \mathrm{mg} \cdot \mathrm{L}^{-1} \mathrm{GA}$ & 1 & 2.29 & 0.1316 \\
\hline $\mathrm{L}: 500$ vs. $1500 \mathrm{mg} \cdot \mathrm{L}^{-1} \mathrm{GA}$ & 1 & 14.12 & 0.0002 \\
\hline \multicolumn{4}{|l|}{ VAPA $024-22 / 5^{\circ} \mathrm{C}$} \\
\hline $\mathrm{M}: 1000$ vs. $1500 \mathrm{mg} \cdot \mathrm{L}^{-1} \mathrm{GA}$ & 1 & 66.13 & $<0.000$ \\
\hline $\mathrm{K}: 1000$ vs. $1500 \mathrm{mg} \cdot \mathrm{L}^{-1} \mathrm{GA}$ & 1 & 3.44 & 0.0652 \\
\hline $\mathrm{L}: 1000$ vs. $1500 \mathrm{mg} \cdot \mathrm{L}^{-1} \mathrm{GA}$ & 1 & 1.51 & 0.220 \\
\hline \multicolumn{4}{|l|}{ VAPA $024-20 / 13{ }^{\circ} \mathrm{C}$} \\
\hline $\mathrm{M}: 1000$ vs. $1500 \mathrm{mg} \cdot \mathrm{L}^{-1} \mathrm{GA}$ & 1 & 0.01 & 0.943 \\
\hline $\mathrm{K}: 1000$ vs. $1500 \mathrm{mg} \cdot \mathrm{L}^{-1} \mathrm{GA}$ & 1 & 3.76 & 0.053 \\
\hline $\mathrm{L}: 1000$ vs. $1500 \mathrm{mg} \cdot \mathrm{L}^{-1} \mathrm{GA}$ & 1 & 9.83 & 0.002 \\
\hline
\end{tabular}

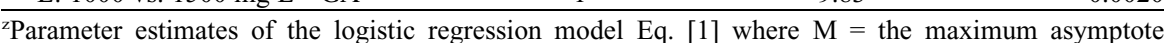
(theoretical maximum cumulative percentage), $\mathrm{K}=$ rate of increase, and $\mathrm{L}=$ lag time or time to reach $50 \%$ of $\mathrm{M}$.

As with the VAPA 023 accession, cumulative VAPA 024 seed germination grown under $22 / 5^{\circ} \mathrm{C}$ increased with increasing GA$\mathrm{K}$ concentration. Seeds treated with 500 and $1000 \mathrm{mg} \cdot \mathrm{L}^{-1} \mathrm{GA}-\mathrm{K}$ germinated similarly at $50 \%$ and $55 \%$, respectively, whereas seed germination with $1500 \mathrm{mg} \cdot \mathrm{L}^{-1} \mathrm{GA}-\mathrm{K}$ was $75 \%$ (Fig. 4; Table 3). All treated seed had $\mathrm{M}$ greater than the $38 \%$ germination of control seeds. Finally, VAPA 024 seeds grown under $20 / 13{ }^{\circ} \mathrm{C}$ also had a consistent $\mathrm{M}$ increase from $61 \%$ for the control up to $74 \%$ for the 1000 and $1500 \mathrm{mg} \cdot \mathrm{L}^{-1} \mathrm{GA}-\mathrm{K}$ treatments (Fig. 5).
The rate of increase $(\mathrm{K})$ was influenced by GA-K treatments only when VAPA 024 seeds were germinated under $20 / 13{ }^{\circ} \mathrm{C}$ (Table 3). K increased for VAPA 024 seeds after GA-K treatments whereas VAPA 023 rate did not (Table 4). Germination rates for seeds treated with 500 or $1500 \mathrm{mg} \cdot \mathrm{L}^{-1} \mathrm{GA}-\mathrm{K}$ were similar, whereas the germination rate of seeds treated with $1000 \mathrm{mg} \cdot \mathrm{L}^{-1}$ was higher compared with that of control seeds (Fig. 5). K for seeds treated with 1000 and $1500 \mathrm{mg} \cdot \mathrm{L}^{-1} \mathrm{GA}-\mathrm{K}$ were similar, and VAPA 024 seeds showed increased speed of germination after GA-K 


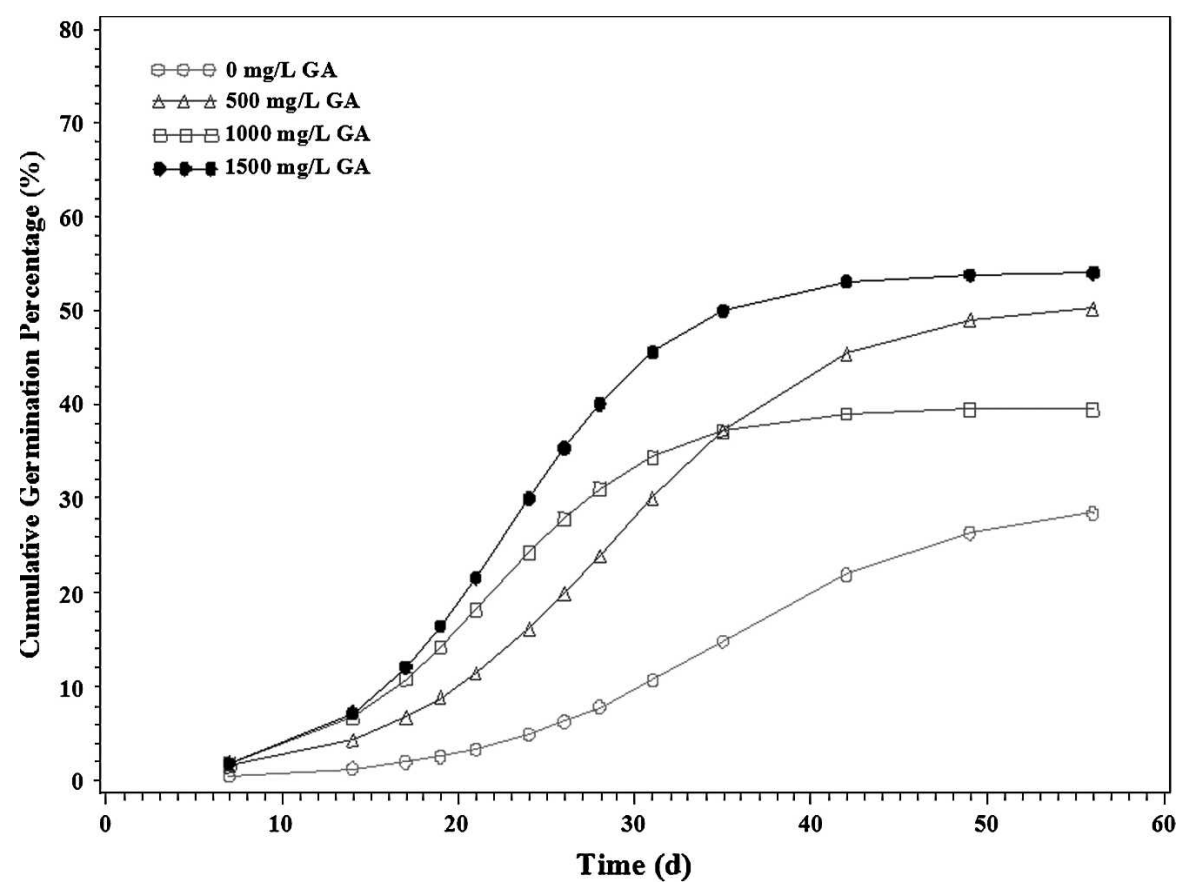

Fig. 3. Estimated logistic regression lines for accession VAPA 023 seeds under $20{ }^{\circ} \mathrm{C}$ day $/ 13{ }^{\circ} \mathrm{C}$ temperatures and a 12-h photoperiod treated with four gibberellic acid potassium salt (GA-K) treatments.

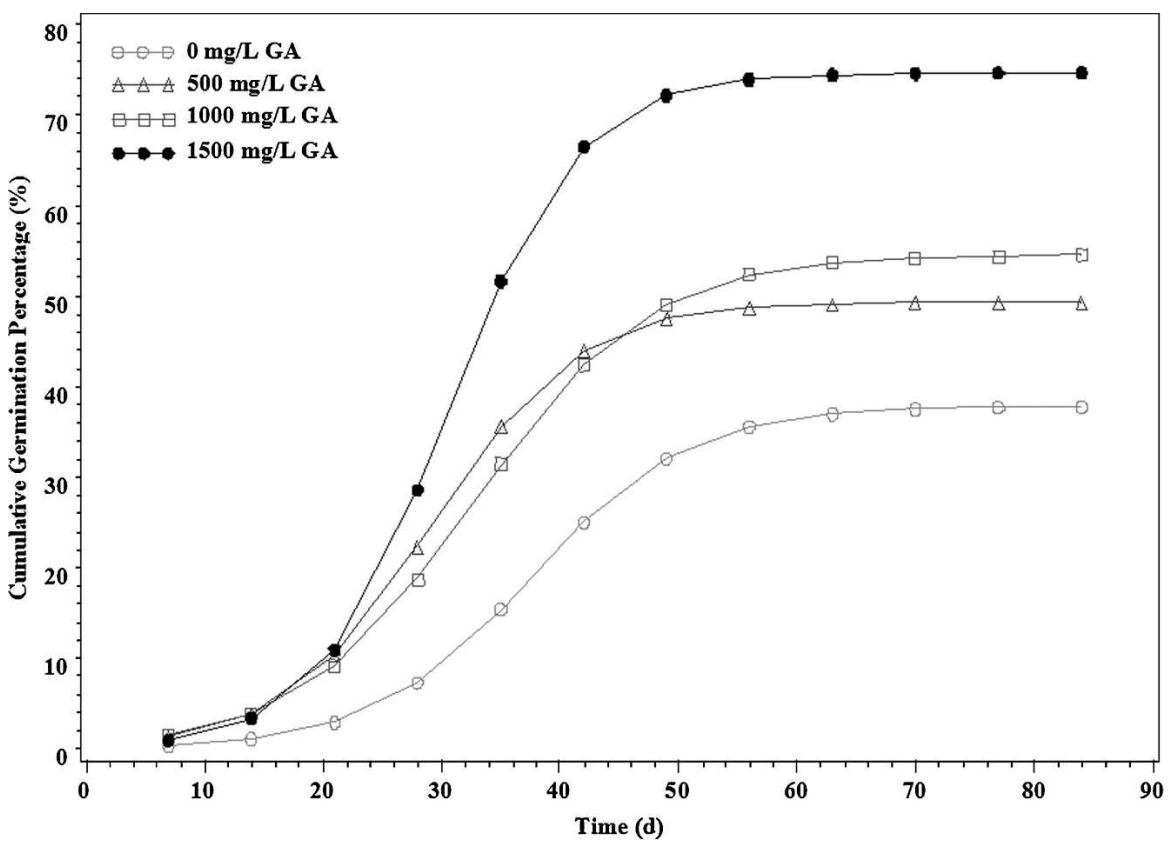

Fig. 4. Estimated logistic regression lines for accession VAPA 024 under $22{ }^{\circ} \mathrm{C}$ day $/ 5{ }^{\circ} \mathrm{C}$ night temperatures and a 12-h photoperiod treated with four gibberellic acid potassium salt (GA-K) treatments.

treatments whereas VAPA 023 did not (Table 4).

All GA-K treatments significantly reduced $\mathrm{L}$ for seed germination compared with the control except when VAPA 023 seeds were grown under $22 / 5{ }^{\circ} \mathrm{C}$ (Tables 1 and 3 ). However, When comparing the $\mathrm{L}$ of $32 \mathrm{~d}$ of seeds treated with the $1000 \mathrm{mg} \cdot \mathrm{L}^{-1}$ GA-K with seeds treated with $0 \mathrm{mg} \cdot \mathrm{L}^{-1} \mathrm{GA}$ - decreased significantly from $38 \mathrm{~d}$ to $29 \mathrm{~d}$ for control and $500 \mathrm{mg} \cdot \mathrm{L}^{-1}$, respectively (Fig. 4). In addition, as the GA-K concentrations increased from 1000 to 1500 $\mathrm{mg} \cdot \mathrm{L}^{-1}$, seeds germinated at similar L (Table 4). For VAPA 024 seeds grown under $20 / 13$ ${ }^{\circ} \mathrm{C}$, the $1000 \mathrm{mg} \cdot \mathrm{L}^{-1} \mathrm{GA}-\mathrm{K}$ treatment significantly reduced L from $29 \mathrm{~d}$ (control) to $18 \mathrm{~d}$ (Fig. 5).

A relatively low germination level of $47 \%$ and prolonged germination times of $38 \mathrm{~d}$ to first radical emergence have been reported for red huckleberry seeds with no GA (Vander Kloet, 1983). In our study, up to $75 \%$ germination and an $\mathrm{L}$ as short as $18 \mathrm{~d}$ were obtained as a result of endogenously applied GA. These results support reports of improved seed germination with GA treatments in related Vaccinium species (Devlin and Karczmarczyk, 1975; 1977; Maznaya and Lyanguzova, 1999; Smagula et al., 1980), and provide a detailed seed germination description resulting from applied GA.

\section{Conclusions}

Temperature regimens affected red huckleberry germination characteristics. The 22 ${ }^{\circ} \mathrm{C}$ constant temperature regime with a $12-\mathrm{h}$ photoperiod resulted in little to no germination during the test periods, supporting previous findings that red huckleberry seeds require diurnal temperature fluctuations to germinate. Germination conditions with relatively low night temperatures $\left(22^{\circ} \mathrm{C}\right.$ day $/ 5$ ${ }^{\circ} \mathrm{C}$ night) and a $12-\mathrm{h}$ photoperiod produced lower germination percentages than a regime with a warmer night temperature $\left(20^{\circ} \mathrm{C}\right.$ day/ $13{ }^{\circ} \mathrm{C}$ night and 12-h photoperiod). These findings provide valuable information to growers on germination protocols to apply to produce red huckleberry commercially. The increase in germination speed and germination percentages creates a more valuable scenario for commercial production of red huckleberry plants and increases the possibility of finding potential valuable germplasm for plant breeding purposes.

Although the mechanisms of GA-K effects on germination are yet to be determined for red huckleberry seeds, GA-K had a profound effect on germination of dried, cold-stored red huckleberry seeds. GA treatments generally induced seeds to germinate at higher $\mathrm{M}$ percentages with shorter Ltimes compared with control seed germination. The $1000 \mathrm{mg} \cdot \mathrm{L}^{-1}$ and $1500 \mathrm{mg} \cdot \mathrm{L}^{-1}$ treatments produced the highest germination percentages and rates as well as shortest lag times. For breeding programs and huckleberry production, the use of growth regulators can play an important role in optimizing radical emergence and the potential of selecting valuable genotypes as prospective candidates for commercial production. In addition, with more uniform, rapid, and higher percentages, the use of GA-K can be a valuable tool for growers to grow huckleberry plants commercially by making management and marketing more feasible. 


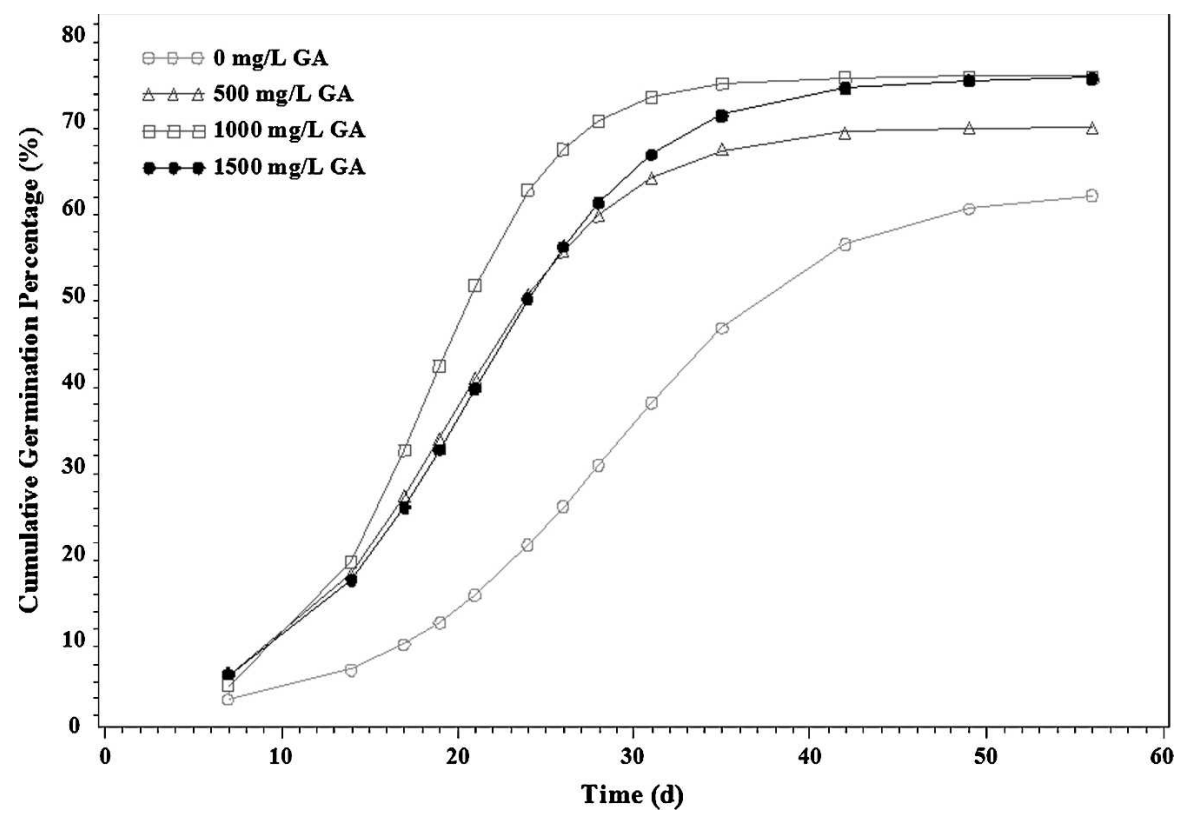

Fig. 5. Estimated logistic regression lines for accession VAPA 024 under $20{ }^{\circ} \mathrm{C}$ day $/ 13{ }^{\circ} \mathrm{C}$ night temperatures and a 12-h photoperiod treated with four gibberellic acid potassium salt (GA-K) treatments.

\section{Literature Cited}

Austin, M.E. and J.S. Cundiff. 1978. Factors affecting rabbiteye blueberry seed germination J. Amer. Soc. Hort. Sci. 103:530-533.

Ballington, J.R., G.J. Galletta, and D.M. Pharr. 1976. Gibberellin effects on rabbiteye blueberry seed germination. HortScience 11:410 411.

Barney, D.L. 2003. Prospects for domesticating western huckleberries. Small Fruits Rev. 2: $15-29$.

Baskin, C.C., P. Milberg, L. Andersson, and J.M. Baskin. 2000. Germination studies of three dwarf shrubs (Vaccinium, Ericaceae) of northern hemisphere coniferous forests. Can. J. Bot. 78:1552-1560
Lopez, O.A. 2006. Seed and in vitro propagation of Vaccinium species native to Western North America. Univ. of Idaho, Moscow, M.S. Thesis.

Maznaya, E.A. and I.V. Lyanguzova. 1999. Biology of seed germination in some species of Vaccinium L. (translated title). (In Russian). Rastitel'nye Resursy. 35:53-59.

Minore, D., A.W. Smart, and M.E. Dubrasich. 1979. Huckleberry ecology and management research in the Pacific Northwest. Research Note PNW-236. USDA Forest Service Pacific Northwest Forest and Range Expt. Sta., Portland, OR

SAS Institute Inc. 2004. SAS Online Doc. 9.1.3. Cary, NC.

Shafii, B. and D.L. Barney. 2001. Drying and cold storage affect germination of black huckleberry seeds. HortScience 36:145-147.

Smagula, J.M., M. Michaud, and P.R. Hepler. 1980. Light and gibberellic acid enhancement of lowbush blueberry seed germination. J. Amer. Soc. Hort. Sci. 105:816-818.

Stark, N. and S. Baker. 1992. The ecology and culture of Montana huckleberries: A guide for growers and researchers. Misc. Pub. 52. Montana Forest and Conservation Expt. Sta.. School of Forestry, Univ. of Montana, Missoula.

Stushnoff, C. and F. Hough. 1968. Response of blueberry seed germination to temperature, light, potassium nitrate and coumarin. Amer. Soc. Hort. Sci. 93:260-266

Taiz, L. and E. Zeiger. 2002. Plant physiology, 3rd ed. Sinauer Associates Publishers, Sunderland, MA.

Thompson, K. and J.P. Grime. 1983. A comparative study of germination responses to diurnally fluctuating temperatures. J. Appl. Ecol. 20:141-156

Thompson, K., J.P. Grime, and G. Mason. 1977. Seed germination in response to diurnal fluctuations of temperature. Nature 267:147-149.

Vander Kloet, S.P. 1983. Seed and seedling characters in Vaccinium § Myrtillus. Le Naturaliste Can. 110:285-292.

Vander Kloet, S.P. 1988. The genus Vaccinium in North America. Publication 1828. Res. Branch, Agr. Can., Ottawa, Canada. 